\title{
Boguslaw NOWOWIEJSKI
}

\section{MAKARONIZMY KOŃCA XX WIEKU}

$\mathrm{Za}$ istotę makaronizowania uznaje się dość powszechnie współwystępowanie w obrębie jednego tekstu, na określonej zasadzie, elementów leksykalnych co najmniej dwu systemów językowych. Mimo pozornej zgodności poglądów makaronizowanie nie może jednak uchodzić za pojęcie jednoznaczne.

Wśród historyków języka polskiego możemy się spotkać z kilkoma zasadniczymi sposobami rozumienia makaronizmu. Zwolennicy ujęcia tradycyjnego uznaja makaronizowanie za zjawisko stylistyczno-leksykalne znamienne dla języka literackiego $\mathrm{i}$ potocznego niemal całej doby średniopolskiej $^{1} \mathrm{i}$ wyróżniają $\mathrm{w}$ jego obrębie dwa podstawowe nurty ${ }^{2}$. W znaczeniu genetycznie pierwszym, w makaronizowaniu widzi się żartobliwe latynizowanie, polegające przede wszystkim na dodawaniu do wyrazów polskich końcówek łacińskich. Kanonicznym przykładem takiego makaronizowania, dla którego wzór stanowiły wiersze renesansowych poetów włoskich ${ }^{3}$, jest Carmen macaronicum Jana Kochanowskiego.

Najbardziej jednak znaną odmianą makaronizmu tradycyjnego (historycznego, właściwego?) jest powszechny wśród polskiej szlachty XVII i pierwszej połowy XVIII wieku zwyczaj wplatania w polski tekst wyrazów i zwrotów łacińskich w celu wywołania wrażenia "uczoności” autora ${ }^{4} \mathrm{Za}$ klasyczne przykłady polskich tekstów makaronicznych tej epoki uchodzą m.in. pamiętniki Jana Chryzostoma Paska ${ }^{5}$ i popularna encyklopedia kultury saskiej,

\footnotetext{
Por. T. Lewaszkiewicz, W.R. Rzepka, Uwagi o leksyce makaronicznej w tekstach polskich XVII w., Z Polskich Studiów Slawistycznych, seria 5, Jezzykoznawstwo, Warszawa 1978, s. 271.

2 Por. Z. Leszczyński, Echa makaronizowania, „Roczniki Humanistyczne”, t. XXX-XXXI, 1982-83, s. 97.

3 Encyklopedia językoznawstwa ogólnego pod red. K. Polańskiego, wyd. II, Wrocław 1999.

4 Encyklopedia języka polskiego pod red. S. Urbańczyka i M. Kucały, wyd. III, Wrocław 1999.

5 Por. m.in. W. Kuraszkiewicz, Makaronizmy w pamiętnikach Jana Chryzostoma Paska, w: Barokw polskiej kulturze, literaturze i języku, Warszawa-Kraków 1992, s. 101-108.
} 
czyli Nowe Ateny Benedykta Chmielowskiego ${ }^{6}$. Melanż polsko-łaciński staje się jednocześnie wymogiem stylowym, manierą stylistyczną baroku i czasów saskich. Z ostrą krytyką tego zwyczaju występowali prekursorzy polskiego oświecenia, m.in. Stanisław Konarski w rozprawie $O$ poprawie wad wymowy, Michał Abraham Trotz we wstępie do swojego słownika czy Franciszek Bohomolec w Rozmowie o języ ku polskim ${ }^{7}$.

W przedstawionych ujęciach zwracają uwagę dwa wspólne elementy definicyjne. Po pierwsze - fenomen makaronizowania przypisuje się konkretnej epoce w historii języka polskiego, po drugie - za makaronizm, czyli jednostkę tekstu makaronicznego uznaje się wyłącznie elementy leksykalne o łacińskiej etymologii. Nietrudno zarazem dostrzec, że oba ujęcia cechuje zdecydowanie odmienne pojmowanie zarówno zakresu znaczeniowego samego makaronizmu, czyli makaronicznej jednostki leksykalnej, jak i celu, sposobu i charakteru jej wykorzystania w tekście.

Mimo że badacze na ogół wyraźnie odróżniają latynizmy, czyli jednostki łacińskiego pochodzenia zaadaptowane do warunków systemowych języka polskiego, od cytatów, czyli oryginalnych łacińskich wyrazów i wyrażeń $^{8}$, to przecież nie ma pełnej zgody co do tego, czy makaronizmami są wyłącznie oryginalne cytaty łacińskie, czy także - w mniejszym lub większym stopniu - przyswojone zapożyczenia.

Z przywołanych wyżej definicji wynika ponadto, że jednostką tekstu makaronicznego może być zarówno hybrydyczna struktura morfemowa polskołacińska wykorzystywana szeroko w poezji makaronicznej, jak też wyraz, wyrażenie, zwrot, zdanie, a nawet większy fragment tekstu będący całością formalno-semantyczną lub nie stanowiący takiej zintegrowanej całości.

Spojrzenie na makaronizowanie $\mathrm{z}$ perspektywy funkcjonalnej każe uznać je za zjawisko metajęzykowe wyrażające się w żartobliwej zabawie w słowa lub stylistycznej manierze języka artystycznego. W tworzeniu tekstu makaronicznego można jednak widzieć także zwyczaj społeczny, który pozwala

6 Por. H. Rybicka-Nowacka „Nowe Ateny” Benedykta Chmielowskiego. Metoda, styl, język, Warszawa 1974 (zwłaszcza s. 64-92).

7 Por. W. Taszycki, Obrońcy języka polskiego (wiek XT-גTIII), Wrockaw 1953 (zwl. s. 258-264. 275-310).

8 Por. S.Dubisz, Latynizmy i makaronizmy w dwóch listach Marii Ludwiki Gonzagi z 1657 r., w: Wokót języka. Rozprawy i studia poświęcone pamięci prof. M.Szymczaka, Wrocław 1988, s. 121-130. 
przypisać jego twórcy cechę „uczoności”, (pseudo)erudycji albo przynależność do uprzywilejowanej grupy społecznej.

Poza ujęciem tradycyjnym, które bierze pod uwagę jedynie makaronizowanie właściwe, w literaturze językoznawczej możemy spotkać jeszcze inne, mniej lub bardziej rygorystyczne, sposoby rozumienia interesującego nas terminu.

$\mathrm{Na}$ przykład, w konsekwencji postrzegania makaronizowania jako zjawiska przypisywanego tylko wybranej epoce i związanego z pochodzeniem elementów obcojęzycznych $\mathrm{z}$ jednego źródła, nierzadko utożsamia się to zjawisko $\mathrm{z}$ latynizowaniem $\mathrm{w}$ ogóle, czyli nasycaniem polskiego tekstu różnorodnymi wtrętami z języka łacińskiego.

W bardziej rygorystycznej interpretacji, której podstawę stanowią kryteria wewnątrzjęzykowe, zakres znaczeniowy tekstu makaronicznego zawęża się do takich tylko wypadków, kiedy - jak ma to miejsce w wypadku typowych tekstów makaronicznych XVII i XVIII w. - zawiera on, obok innych, także cytaty czasownikowe, wchodzące $w$ ścisłe związki składniowe albo gramatyczne z wyrazami rodzimymi'. Co innego, że ten rygoryzm jest nie do końca konsekwentny, wyznaczając bowiem $\mathrm{z}$ jednej strony wyraziste ograniczenia gramatyczne zjawiska, zezwala zarazem na rozszerzenie jego zakresu znaczeniowego na inne - niż łacina - języki.

Przy szerszym tego słowa rozumieniu, dopuszcza się interpretację makaronizowania jako zjawiska inkrustowania tekstu zbudowanego z materiału jednego języka oryginalnymi wyrazami, wyrażeniami, frazami i większymi jednostkami tekstowymi należącymi do innego języka.

W najbardziej liberalnej wersji, która znajduje zastosowanie w naszych rozważaniach, za polski tekst makaroniczny uznamy taki tekst w języku polskim, w którym mamy do czynienia $\mathrm{z}$ oryginalnymi obcojęzycznymi wtrętami oraz (częściowo przyswojonymi) zapożyczeniami z obcego języka naturalnego.

W tym miejscu warto odpowiedzieć na pytanie, co uprawnia do takiego szerokiego rozumienia terminu silnie utrwalonego $\mathrm{w}$ polskiej terminologii językoznawczej w węższym sensie (sensach).

9 Por.Z. Leszczyński, op.cit.. s. 100. 
1. Jako główny powód można by tu podać, dobrze widoczne na gruncie wielu odmian współczesnej polszczyzny, zwłaszcza języka mediów, w tym reklamy, języka nauki i polityki czy niektórych odmian zawodowych i środowiskowych (por. socjolekt informatyków" , „snowboardzistów" ", prezenterów i wykonawców muzyki rockowej ${ }^{12}$ itp.), próby zachwiania dominującej pozycji języka polskiego przez wprowadzanie do tekstów polskich dużej liczby obcych wtrętów oraz nowych, tylko częściowo zaadaptowanych, zapożyczeń. Przyjętą postawę uzasadnia dodatkowo duże zróżnicowanie formalne, semantyczne, stylistyczne, etymologiczne, chronologiczne obcych elementów leksykalnych, ich funkcje w tekście, ale też nowe, ciekawe zjawiska towarzyszące tradycyjnemu funkcjonowaniu makaronizmów.

Mam tu na uwadze przede wszystkim dowody dobrej znajomości obcych wyrazów i wyrażeń oraz przejawy specyficznej asymilacji obcego cytatu w polszczyźnie, który - zachowując postać oryginału - wchodzi w polski kontekst semantyczny i uwarunkowania stylistyczne. Ten mechanizm adaptacyjny ujawnia się m.in. w wypadku szczególnego rodzaju derywacji analogicznej, w której ramach powstają nowe konstrukcje makaroniczne wzorowane na już istniejących jednostkach.

Przykładem, który dobrze ilustruje ten mechanizm, jest seria złożeń z drugim członem -gate, który od czasów pamiętnego Watergate, stał się w języku międzynarodowej publicystyki synonimem afery, skandalu. Wykorzystanie tego wzorca pozwoliło na powołanie do życia, znanych i z naszej prasy, złożeń: Irangate (sprawa przemytu broni z USA do Iranu), Sznapsgate (sprawa przemytu spirytusu do Polski), zippergate albo Monicagate (erotyczny skandal w Białym Domu), VATgate (afera związana z unikaniem płacenia VAT-u), Kohlgate (sprawa niejawnego finansowania partii chadeckich w Niemczech), Kremlgate (afera korupcyjna w Rosji).

Innym, często wykorzystywanym w funkcji drugiego członu nowych kompositów, elementem jest słówko -land. Na wzór konstrukcji jeansland, legoland, utworzono nowe: chamoland, haraczland, papaland, bakterioland.

10 Por. J. Matusiak, Polskie stownictwo komputerowe, „Poradnik Językowy” 1997, z.1, s. 24-28.

1 Por. M. Pol, Góra stanęta na gtowie, „Magazyn Gazety Wyborczej” z 21.03.1997 r.

12 Por. G. Majkowska, H. Satkiewicz, Język w mediach, w: Polszczyzna 2000. Orędzie o stanie języka polskiego na przełomie tysiq̨cleci, red. W. Pisarek, Kraków 1999, s. 182. 
Analogią do zapożyczonych leksemów: Superman, Batman, należy tłumaczyć powstanie rodzimego VATmana. W ostatnich miesiącach, jak grzyby po deszczu mnożą się połączenia wzorowane na skrócie od electronic mail, czyli email: e-business, e-bank, e-kino, e-gospodarka, e-księgarnia, e-kreator, ecudotwórca itp. Obecność w polszczyźnie konstrukcji T-shirt pozwoliła na utworzenie nowego połączenia $T$-styl.

$\mathrm{Z}$ derywacją analogiczną mamy do czynienia także w wypadku powoływania do życia, na wzór zestawień homo sapiens, homo ludens, nierzadko metaforycznych i emocjonalnie nacechowanych zestawień typu: homo politicus, homo europeicus, homo sovieticus, homo varsoviensis, żartobliwe: homo bestialis, homo electronicus, homo hypocritus ${ }^{13}$.

Tylko zakładanie powszechnej znajomość powiedzeń i sentencji, w rodzaju: homo homini lupus est, ars longa, vita brevis, vox populi, vox dei, de gustibus non est disputandum, nec Hercules contra plures, nihil novi sub sole, to be or not to be, last, (but) not least pozwala na swobodne ucięcie kwestii, np. homo hominini..., ars longa.., vox populi..., de gustibus.., nec Hercules..., nihil novi..., to be or..., last but..., i oddanie inicjatywy w ręce odbiorcy komunikatu, którego zadaniem jest jej uzupełnienie.

Podobny osąd wydaje się uprawniony także w wypadkach, kiedy równolegle i na zasadzie pełnej wymienności funkcjonują wersja oryginalna i jej polski odpowiednik, zwłaszcza w zakresie łacińskich maksym i sentencji typu: aleia iacta est - kości zostały rzucone, manus manus lavat - ręka rękę myje, pecunia non olet - pieniadze nie śmierdza, fiat lux - niech będzie światto, cogito ergo sum-myśle, więc jestem.

„Oswojenia" obcego elementu leksykalnego wyrazu, wyrażenia lub zwrotu dowodzą też żartobliwe parafrazy: in vino veritas $>>$ in vino... wino, c'est la vie >> se la...wino.

Uwagę zwraca ponadto dość powszechny dziś zwyczaj wyzyskiwania makaronizmów, kompletnych jednostek lub ich fragmentów, w funkcji wyeksponowanych elementów tekstów prasowych, a więc tytułów, podtytułów i

$13 \mathrm{~W}$ języku potocznym sp̧otkać możemy jeszcze rubaszne, a może nawet prostackie homo niewiadomo ( $w$ odniesieniu do osoby o nieokneśśnych preferencjach seksualnych lub mało wyrazistych cechach płciowych). 
nagłówków. W głównej mierze dotyczy to makaronizmów angielskich (Fair Play, Playback, Last Minute, Know-How, Real Party. English First, Hyde Park) i łacińskich (Pro publico bono, Sancta simplicitas, Dura lex, Vox populi), z rzadka francuskich: Menu, Dossier, Déjà vu(e).

Zdarza się też coraz częściej, że elementy makaroniczne, stanowiące całość formalno-semantyczną lub będące jej fragmentem, wplata się, w celu zwiększenia ekspresji wypowiedzi, zwłaszcza wywołania komizmu językowego, w nietypowe konteksty, jak w przykładach: Socjalizm ante portas, NATO ante portas, Aldi ante portas, Polonia ante portas, Pizza à la Stalin, Lex Putin, Homo Kisiel, Łukaszenkoland, Liberte, Egalite, Internete!

Powszechnie zderza się też różnojęzyczne elementy makaroniczne $\mathrm{z}$ wyrażeniami rodzimymi lub dawnymi zapożyczeniami w tytułach i nagłówkach, jak w przykładach: Criminal samba, Etno polo, Koncertowy dumping, Dramaturgia newsu, Inwazja hakerów, Zawód killer, Wiara yuppies, Polskie lobby, Polskie dossier, Dossier Wariata, Jaselkowy song, Moskiewskie puzzle, Papaland Wadowice, Geszeft ponad wszystko, Klub oldbojów, Plaster z mikrochipem. Ten zabieg stylistyczny, wzmacniając ekspresję wypowiedzi, służy zaciekawieniu czytelnika i prowokuje go do lektury tekstu.

2. Za szerokim rozumieniem makaronizowania przemawiają także inne względy, przede wszystkim to, że nie można w nim widzieć wyłącznie fenomenu językowego, który cechuje ograniczenie: w czasie - do wybranej epoki, w materii - do elementów jednego języka, w funkcji - do maniery stylistycznej czy tylko wykładnika pozycji społecznej. Obserwacja losów języka polskiego dowodzi bowiem tego, że makaronizowanie należy do grupy zjawisk, które są swoistym refleksem kontaktowania się języków. Zachodzi więc zawsze, kiedy języki lub ich odmiany wchodzą ze sobą w kontakt. Jako fakt językowy stale obecny, ale osadzony w konkretnych uwarunkowaniach, makaronizowanie ulega jedynie określonym modyfikacjom.

Uwzględnienie tego toku rozumowania pozwala uwzględnić w badaniach nie tylko właściwe, a więc historyczne teksty makaronizowane, ale także współczesne polskie teksty przesycone obcymi cytatami i (w sporej części mało przyswojonymi) zapożyczeniami z języków obcych. W celu uniknięcia niejednoznaczności i konfliktu z tradycyjnym zakresem użycia terminu makaronizm, wobec tak pojmowanego makaronizowania można by 
posłużyć się terminem, ,neomakaronizm“.

Za teksty (neo)makaroniczne. w powyższym rozumieniu, można zatem uznać liczne publikacje prasowe ukazujące się w aktualnie wydawanych czasopismach. Jedno $\mathrm{z}$ nich, mianowicie poznański tygodnik społecznopolity'czny „Wprost” stało się przedmiotem naszej uwagi w okresie ostatnich siedmiu lat (1994-2000). Z tego źródła pochodzi ogromna większość, bo ok. $80 \%$ analizowanego materiału językowego. Materiał uzupełniający i porównawczy został natomiast zaczerpnięty z tekstów zamieszczonych w "Polityce” i „Gazecie Wyborczej”.

Już z pobieżnego oglądu interesujących nas publikacji wynika, że w całym analizowanym okresie $\mathrm{w}$ tekstach zróżnicowanych co do wielkości, charakteru i treści, występują liczne elementy obcojęzyczne, w tym dobrze zadomowione w polszczyźnie zapożyczenia, na których tle silnie zaznaczaja swoją obecność makaronizmy, czyli jednostki w najmniejszym stopniu nie przyswojone przez polszczyznę oraz przejęcia tylko częściowo asymilowane, a więc noszące, tak jak cytaty, wyraziste ślady obcości. $Z$ formalnego punktu widzenia są to głównie wyrazy i wyrażenia, rzadziej zwroty i pełne frazy, te ostatnie zwykle w postaci maksym, sentencji, powiedzeń. Poza postacią różni je etymologia, zakres tematyczny, nacechowanie stylistyczne i frekwencja tekstowa.

Zgodnie $\mathbf{z}$ oczekiwaniami, $\mathbf{w}$ analizowanym materiale dominuja makaronizmy pochodzenia angielskiego, głównie wyrazy i wyrażenia, obsługujące właściwie wszystkie zakresy znaczeniowe: życie polityczne (polish jokes, first lady, politically correct, political fiction, good news is no news, gentlemen's egreement, splendid isolation, restricted area, freeman 'zwolennik nieograniczonej wolności w życiu społecznym'), ekonomię, organizację i zarządzanie, biurowość (joint venture, small businnes, business-plan, businessmeeting, business-woman, business-lunch, managers lunch, top management 'zarząd', comuting manager, junior manager, sales manager, information manager, money manager 'zarządca pieniędzmi', company doctor 'dosł. lekarz firm', service worker 'pracownik usługowy', knowledge worker 'pracownik 
wykorzystujący wiedzę ${ }^{\prime 4}$, equal opportunities 'polityka równych szans przy zatrudnianiu', incentive travel 'podróż motywacyjna', mutual found 'fundusz powierniczy', hedge found 'agresywny fundusz', trans national corporation 'firma mająca filie w wielu krajach', public relation, booklet 'reklamowa próbka powieści', product placement 'reklama produktu przez umieszczenie go w filmie', venture capital 'fundusz wspierania małych przedsiębiorstwa', mass market, emerging market 'rynek rozwijający się', home market, duty-free, franchising, blue chip 'czołowa spółka giełdowa', fixing, ratting), leksykę tzw. technologii przyszłości, zwłaszcza in formatyczną (plug and play, on line, know how, notebook, cybersquatting 'rejestrowanie cudzych internetowych domen i sprzedawanie ich z zyskiem', city-call 'funkcja telefonu', callback 'automatyczne oddzwanianie', high-tech, hacker, provider, display, downlight 'oświetlenie w podłodze', virtual reality, upgrade, sotfware, hardware, easy touch 'urządzenie do programowania kuchenki'. Liczne makaronizmy angielskiego pochodzenia znajdziemy $w$ słownictwie dotyczącym szeroko rozumianej sfery życia społecznego (public choise 'teoria wyboru', target group 'dosł. grupa celowa', middle class, upper class, class property, class of knowledge 'klasa średnia', sexual harassment 'molestowanie', mobbing 'stwarzanie wrogiej atmosfery w pracy', quality people 'ludzie o wysokiej pozycji społecznej', high society, high life, yuppie, sunnyboy 'dandys', prinuptial agreement 'umowa przedmałżeńska', baby-sitter, copywriter, ghostwriter, generation next, computer kids generation, skinhead, new wave, new age, learnig by doing 'nauka przez działanie', business class, economic class, social security, born to kill 'urodzony zabójca', green zone 'zielona strefa' shadow woman 'kobieta pozostająca w cieniu', working girl 'pracująca dziewczyna', good working girl 'wzięta modelka', wishfull thinking 'myślenie życzeniowe'), w tym nauki (native speaker, basic lavel, mother tonge, crashtest, by-pass).

Bardzo rozległą reprezentacje mają angielskie makaronizmy $\mathrm{w}$ dziedzinie rozrywki, zwłaszcza stanowiącej domenę mediów masowych, telewizji i filmu (show-business, prime time, news, spot, talk-show, reality show,

${ }^{14}$ Wielu językoznawców i publicystów zwraca uwage na niepokojący, bo wynikający głównie ze snobizmu, a nie prawdziwej potrzeby, zwyczaj nadużywania obco brzmiących tytułów, zwłaszcza nazw funkcji i stanowisk biurowych. Zob. M.Klimkowski, Dyktatura tytułów, „Wprost” z 13.01.2000, s. 60-61. 
cover story 'reportaż', weatherman 'zapowiadacz pogody', snooker, slasher 'dosł. bokser walący na oślep', przen. 'gatunek filmu', playwriter, pay-perview, blacout 'dowcip', sitcom, peep show, sex-hit, love parade, call girl, party line, air show, ultimate fight 'walka wszechwalk', music-business, world music, pop-music, hig-heat, ethnic music, acid-jazz, street-jazz, dancefloor-jazz, haevy metal, root raegge, top chart 'lista przebojów', evergreen, boysband, powerplay 'przebój', walkman, tour manager 'odpowiedzialny za trasę koncertową', body building 'kulturystyka', stretching, step reebok, keep smiling, looking good, heauty team, body wrapping 'zabieg odmładzania skóry', neat 'wzór na krawacie', proll-party, 'bal tandeciarzy', house party, jump party, techno party, sex-parrty, garden-party, joint, eckstasy).

Stale zwiększa się liczba makaronizmów angielskich z zakresu sportu i turystyki (play off, playmaker, dream team, draft, regular season, couch, slam dunk 'wsad (piłki do kosza)', drop shot 'skrót (w tenisie)', tie break, pole position 'pierwsze pole startowe (w wyścigach w samochodowych)', wrestling, paint hall, squash, skating inline 'łyżworolki', snowboard, skateboard 'jazda na deskorolce', kickhoard 'jazda na hulajnodze', jogging, windsurfing, tramping, caravaning, around the world, over stop 'przerwa w podróży', youth hostel 'schronisko dla młodzieży', mohil home 'dom na kołach', city car, car of the year, hatchback, airbag, catering 'obsługa'). Osobne miejsce zajmuje tu coraz bogatsze i dynamicznie się rozwijające nazewnictwo związane $\mathrm{z}$ tzw. sportami ekstremalnymi i ekstrawaganckimi: ski-ekstreme 'narciarstwo ekstremalne', skiring 'jazda na nartach za koniem', tracking 'skoki spadochronowe ze szczytów gór, paragliding 'skoki na spadolocie', kanioning 'szaleńcze spływy rwącymi rzekami', rafting 'pontonowy spływ rzeką', bungee jumping 'skoki na linie', downhill 'zjazd na rowerze ze stromego zbocza', bikeboard, wakeboard 'jazda na desce za motorówką', survival 'sztuka przetrwania', baby jogger 'wyścigi wózków dla dzieci'.

Bez makaronizmów angielskich nie może się także obejść sfera konsumpcji. Reprezentuja ją m.in. fast food, drink bar cheesburger, chickenburger, chip, snac, pop corn, long drink, lunch, hot-dog i inne. 
Wśród przywołanych w wyborze cytatów zwracają uwagę liczne okazjonalizmy ${ }^{15}$, których zaświadczenia sa jednostkowe, np. frazy: in the long run we all are dead 'na dłuższą metę pomrzemy wszyscy', the people have spoken 'lud przemówił', think of it before 'najpierw się zastanów', business as usual, czy wyrażenia: code sharing 'kod koordynacji (lotów)', stock picker 'dosł. wybieracz akcji', creative center, keep busy 'ucieczka w aktywność', get away 'zmiana miejsca zamieszkania', interest future 'kontrakt przyszłościowy', sundowners party 'przyjęcie sponsorowane', flirty fishing 'miłosne łowy', love bombing 'dosł. bombardowanie miłością', flower power 'siła kwiatów'.

Nie brak jednak i takich wyrażeń, które mają szanse pozostać w języku polskim na dłużej, niektóre już się zadomowiły, jak: joint venture, small business, last minute, public relation, paint ball, pole position, dream team, dumping, lobby, developer, snowboard, windsurfing, billboard. Pomyślną przyszłość w polszczyźnie mają zapewnioną zwłaszcza samodzielne leksemy, które nie dość, że bez większego trudu wchodzą w polskie konteksty składniowe, to na gruncie języka polskiego towarzyszą im już wyrazy pochodne, przede wszystkim przymiotniki na -owy: weekendowy, windsurfingowy, dumpingowy, leasingowy, rattingowy, franchisingowy, snowboardowy, baseballowy, softwarowy, hardwarowy, undergroundowy, cateringowy, rzadziej na -ski: developerski, dealerski, i inne np. rzeczownikowe na -ista//-ysta: snowboardzista, skateboardzista, lobbysta lub -owiec: surferowiec, skateboardowiec, bikeboardowiec.

Wrażenie obfitości makaronizmów angielskiego pochodzenia na gruncie współczesnej polszczyzny pisanej potęguje obecność wielu dawniej przejętych angielskich wyrazów i wyrażeń, które mimo upływu czasu nie poddały się adaptacji lub uległy jej tylko częściowo. Charakterystyczne, że w ich liczbie znalazły się nie tylko sentencje i powiedzenia, typu: last but not least, to be or not to be, ale liczne wyrażenia np.: science fiction, fair play, happy end, night club, love story, high life, high society, pop corn, five o'clock, walkie-talkie oraz pojedyncze leksemy, typu: boom, playback, lohby, casting, management, aparthaid, establishment, handicap, które zwykle najszybciej i najłatwiej poddają się procesowi asymilacji. Co więcej, spora część tych „starych”

$15 \mathrm{Na}$ małą liczbę często używanych anglicyzmów we współczesnym języku polskim kilkakrotnie zwracała uwage E. Mańczak-Wohlfeld. Por. m. in. Najnowsze zapożyczenia angielskie w polskiej prasie, ..Poradnik Jęz̧.kowy" 1997, nr 3. s.84. 
makaronizmów (niektóre $\mathrm{z}$ nich są nawet zaświadczone w słownikach ogólnych języka polskiego), odznacza się wysoką frekwencją tekstową np. fair play, weekend, king size, happy end, hot-dog, non-siop.

Właściwą ocenę stopnia nasycenia analizowanych tekstów makaronizmami angielskiego pochodzenia dodatkowo utrudnia fakt pojawiania się wtórnych makaronizmów ${ }^{16}$, czyli jednostek, które mają spolszczone odpowiedniki, ale na fali wierności etymologicznej przywraca się im postać oryginału: streaptease, camping, caravaning, coctail, leader, offside, outsider, playboy, baseball. W pewnym zakresie proces ten dotyczy również tych anglicyzmów, które mają mniej lub bardziej udane rodzime synonimy, jak: goalkeeper, speedway, couch, team, boss, leitmotiv czy come back.

W jakimś stopniu na ocenę charakteru tekstu ma też wpływ obecność form hybrydalnych, nowych złożeń i zestawień typu: bakterioland, ciuchland, chamoland, Hoffland, saksoland, gangholding, schnapsgate, samogon story, Jurand story, show wyborczy, Piotruś show, w których składzie występuja angielskie komponenty zachowujące postać oryginału lub mu bliskie.

Odrębną kwestią jest obecność w polskich tekstach prasowych wielkiej liczby angielskich i - mniej licznych - hybrydalnych, angielsko-polskich, nazw własnych. Najłatwiej dostrzec je w tekstach reklamowych, ale nie brak ich także w poważnych merytorycznie publikacjach, w których w różnym celu przywołuje się na przykład nazwy wyższych uczelni (Harvard Business Scholl, Massachusetts Institute of Technology, Northwestern University, North Carolina State Univesity, West Point), nazwy organizacji i instytucji (Amnesty International, Business Center Club, National Hockey League), nazwy firm i banków (General Motors Europe, Philips Electronics, Price Waterhouse Cooper, Arthur Andersen Business Consulting, Young Digitall Poland, Intel Technology Poland) i niezbędne w prasie inne tytuły prasowe (New York Times, The New Yorker, Washington Post, Wall Street Journal, Global Finance, Financial Times, Dailly Mirror, Newsweek, National Geographic, New Scientist, Business Week Poland).

Nowego ciekawego materiału makaronicznego w zakresie nazewnictwa własnego dostarczają w ostatnim czasie zamieszczane w wielu czasopismach, w tym we „Wprost”, różnego typu omówienia, zestawienia i rankingi gier

16 Termin S. Dubisza op.cit. 
komputerowych, nagrań płytowych muzyki rozrywkowej, filmów. Z takich właśnie rankingów pochodzą następujące przykłady nazw gier: Planescupe Torment. Freespace, The Sims. Theocracy, Rollercoaster Tycoon, Need for speed porsche. Worms Armageddon. nagran muzycznych: Supernatural, Ray of light, The hest of Rolling Stones, Dark Side of the Moon. Pieces in the Modern Style, Life could he a Dream. Standing on the Shoulders of Giant, Wicked Woman, Bloodflowers i produkcji filmowych: American Beauty, A Bridge to Far. Love Story. Pulp Fiction, Pretly Woman, Easy Rider, Eyes Wide Shut.

Próba określenia charakteru angielskiego makaronizmu w polszczyźnie pisanej końca $\mathrm{XX}$ w. prowadzi do jeszcze innych interesujących wniosków. Zwraca na przykład uwagę swoista zmiana "geografii" makaronizmów angielskiego pochodzenia. W największej liczbie pojawiają się one obecnie $\mathrm{w}$ tekstach poświęconych najnowszej technologii, zwłaszcza mediom i informatyce. Druga dziedzina to sfera konsumpcji i rozrywki, gdzie zdecydowanie na czoło wysuwają się teksty reklamowe. Uderza przy tym, że poza dobrze już znanymi sloganami w rodzaju: No more tears. Wash and go, Nokia connecting people, Kia in gear. Time is money jak grzyby po deszczu rodzą się liczne nowe, jak: Thomson look, listen and live. Sony-go create, Honda. First man, then machine, West. Test it, Atlantic since 1888 swiss made, Professional - language teacher, Consider digitall everyone's invited, Mitsubishi space star, Sony - so real, so sony, Panasonic. Phones with a future, Adidas - active bodies, Siemens - be inspired.

Kolejna, o wiele istotniejsza i chyba bardziej zaskakująca, obserwacja dotyczy stopnia nasycenia analizowanych tekstów angielskimi makaronizmami. Wynika z niej, że w materiale z ostatnich lat liczba interesujących nas wtrętów angielskich jest ogólnie nieco mniejsza niż w tekstach z początku epoki transformacji ustrojowo-ekonomicznej.

Oczywiście jest rzeczą dyskusji, czy ta obserwacja, oparta wprawdzie na dokładnym oglądzie materiału, ale bez wyliczeń statystycznych, może być uznana za obiektywną i wiarygodną. Bez wątpienia bowiem, na naszą ocenę maja wpływ także pozastatystyczne fakty systemowe. Mam tu na myśli na przykład stały proces polszczenia licznych wtrętów angielskich, jak dealer, leasing, lobby, surfing, developer itp., które szybko przyjęły się na gruncie 
języka polskiego i po prostu mniej już zwracają na siebie uwagę swą nieco zatuszowaną obcością.

$\mathrm{Z}$ drugiej strony, jest jednak niezaprzeczalnym faktem mniejsza liczba nowych oryginalnych wtrętów, zwłaszcza okazjonalnych, o efemerydalnym charakterze, które mają zwykle jednostkowe zaświadczenia. Mniejszy repertuar angielskich makaronizmów właściwych pozostaje też $\mathrm{w}$ związku $\mathrm{z}$ rosnącym udziałem w polskich tekstach kalk semantycznych i replik strukturalnych o angielskim rodowodzie.

W niektórych wypadkach możemy mówić wprost o zastapieniu anglicyzmu właściwego repliką strukturalną jak ma to miejsce w przykładach: pierwsza dama (first lady), politycznie poprawny (politically correct), sprzedaż bezpośrednia (network marketing), numer jeden w Europie (number one in Europe), lowca głów (head hunter), opera mydlana (soap oper), pranie pieniędzy (money laudering), liga mistrzów (champions league), electronic mail (poczta elektroniczna), zippergate (afera rozporkowa), język ciala (body language), nagła śmierć (termin sportowy).

$\mathrm{Na}$ skutek coraz lepszej i powszechniejszej znajomości języka angielskiego, zamiast nowych przejęć właściwych pojawiają się także liczne kalki semantyczne: absolutnie, dokładnie, eliminować, kreować, monopolizować, dieta, konferencja, dywizja (dwa ostatnie przykłady to terminy sportowe) ${ }^{17}$.

Jeśli tezę o mniejszym nasyceniu polskich tekstów prasowych makaronizmami właściwymi angielskiego pochodzenia przyjmiemy za zasadna, w konsekwencji musimy też przyznać, że poza wspomnianymi czynnikami wewnętrzno- $\mathrm{i}$ zewnętrznojęzykowymi zjawisko to w znaczącym wymiarze determinują czynniki poza językowe.

I tak, nie bez wpływu na językowe wybory dziennikarzy i publicystów pozostaja zapewne liczne przejawy puryzmu językowego. Mam tu na myśli nie tylko Ustawę o ochronie języka polskiego, ale też liczne publikacje, których autorzy pełni obaw o stan współczesnej polszczyzny alarmują o zagrożeniach, jakie niosą ojczystemu językowi różnopostaciowe zapożyczenia $z$ języków obcych, przede wszystkim angielskiego. Refleksem szczególnej troski o stan

17 Por. A. Markowski, Nowsze anglicyzmy semantyczne w polszczyźnie, „Poradnik Językowy” 1999 , z.2, s. 156-160. 
współczesnego języka polskiego są też konkursy językowe, jak ogłoszony przed kilku laty przez redakcję „Gazety Wyborczej”, a dziś zainicjowany przez dziennikarzy „Polityki”, których bezpośrednim celem jest wyszukiwanie czy konstruowanie rodzimych odpowiedników najnowszych zapożyczeń z języków obcych. W ogólniejszym wymiarze idzie oczywiście o rozbudzenie zainteresowania zagadnieniami poprawności językowej i świadomej troski o stan polszczyzny.

W grę wchodzi także efekt przesytu. Zbyt często i nazbyt licznie przywoływane wtręty i nowe zapożyczenia angielskie, jeszcze do niedawna tak egzotyczne i atrakcyjne, straciły już walor świeżości i ekspresji, „opatrzyły się" i czytelnikom i publicystom.

Kto wie jednak, czy za najistotniejszą przyczynę ograniczenia makaronizmu angielskiego nie należałoby uznać tego, że neoficki okres zachłyśnięcia się angielszczyzną mamy już za sobą. Mija też chyba powoli moda na angielszczyznę ${ }^{18}$, która - stając się koniecznym składnikiem wykształcenia każdego Polaka, utraciła walor niezwykłości i wysokiego prestiżu. Jako zwykły kod porozumiewania się, pozbawiona snobistycznych atrybutów straciła na atrakcyjności, której tak bardzo potrzebują media.

Na tle zmiennych losów anglicyzmów na gruncie polszczyzny lat 90tych bardzo charakterystyczna wydaje się dziś pozycja łaciny. Usunięta z polskich szkół i życia publicznego, powraca do łask, ale w dość szczególnym wymiarze $\mathrm{i}$ charakterze. Dowodzi tego znajdujący się w naszej dyspozycji materiał prasowy. Otóż, udział makaronizmów łacińskich w analizowanych tekstach prasowych pozostaje stale na niezmiennie wysokim poziomie. Zwraca też uwagę to, że dominuje tu stosunkowo ograniczony repertuar jednostek o wysokiej frekwencji, przede wszystkim tzw. przytoczeń koniecznych, ułatwiających syntetyczne i lapidarne przedstawienie sprawy, jak: primo, secundo, stricte, de facto, sensu stricto, et cetera, ad acta, ad hoc, ad personam, a priori, in blanco, vide, verte, in spe, ex aequo, per analogiam, per capita, pro forma, nolens volens, expressis verbis, sui generis, in corpore, in extenso, in continuo ex definitione, sine qua non, mutatis mutandis, post factum, communis opinio, qui pro quo, idee fixe.

18 Powszechna jeszcze w połowie lat 90-tych. Por. G. Sawicka, Norma a problem tzw. „,zapożyczeń”, „Poradnik Językowy” 1995, nr 9-10, s.83. 
Łacina $w$ analizowanych tekstach prasowych to także tradycyjny składnik terminologii prawniczej (in flagranti, corpus delicti, tertium non datur, de iure, votum separatum, vacatio legis, nuptias consensus facit 'zgodne objawienie woli', ius primae noctis 'prawo pierwszej nocy', pro publico bono, per procura, dura lex, sed lex, lex retro non agit, honoris causa), politycznodyplomatycznej (persona non grata, status quo, incognito, liberum veto), medycznej (angina pectoris, in vitro, ex mortuo 'dosł. z martwego, dawca martwy', ex vivo 'dosł. z żywego, dawca żywy'), religijnej (credo, mea culpa, exodus, catharsis, invocatio dei, opus dei, quo vadis domine, ecce homo, memento mori, sacrum, profanum), językoznawczej (oratio recta, dualis, pluralia tantum, nomen proprium, liber chamorum, genus proximum, differentia specifica, nomen actionis, maskulinum, compositum), ale przede wszystkim atrakcyjny środek retoryczny i szerzej - stylistyczny.

W tej roli, czyli stylistycznych ozdobników występują przysłowia, sentencje i powiedzenia znanych lub anonimowych postaci historycznych, np. Roma locuta, causa finita (św. Augustyn), ars longa, vita brevis (Hipokrates), ridentem dicere verum 'śmiejąc się prawdę powiedział' (Horacy), fiat lux (Biblia), cogito ergo sum (Kartezjusz), qui tacet consetire videtur 'kto milczy, zgadza się,, non possumus (Wulgata), pecunia non olet (Wespazjan), gradu diverso, via una 'krokiem różnym, ale jedną drogą', vox populi, vox dei, malum in es 'zły sam w sobie', de gustibus non est disputandum, nec Hercules contra plures, ars boni et aequi 'sztuka dobra i słuszności', scire leges non hoc est verba earum tenere set vim ac potestatem 'znajomość ustaw polega nie na rozumieniu ich słów, lecz sensu i mocy działania', nihil novi sub sole, ad calendas Graecas (Swetoniusz), veni, vidi, vici (Juliusz Cezar), mens agitat molem 'myśl rządzi światem' (Wergiliusz), cuius regio, eius religio, per as pera ad astra, divide et impera oraz bardzo liczne wyrażenia o zróżnicowanej proweniencji, różnym składzie leksykalnym i znaczeniu, np. signum temporis, modus operandi, modus vivendi, deus ex machina, spiritus movens, semper fidelis, gloria victis, primus inter pares, et consortes, ex cathedra, ars amandi, commedia finita, terra incognita, advocatus diaboli, ad mortem defecatum, lege artis, finis regni, castrum doloris 'budowla $\mathrm{z}$ elementami żałobnymi', perpetuum mobile. Towarzyszą im samodzielne leksemy, makaronizmy łacińskie częściowo przyswojone, ale odczuwane przez użytkowników jako 
elementy wyraźnie obce, jak: constans, continuum, dictum, meritum, notabene, memorandum, novum, casus, exemplum, consensus, explicite.

Dążenie do spotęgowania wyrazistości wypowiedzi sprawia, że wyrażenie łacińskie chętnie przywołuje się w tytułach i nagłówkach ${ }^{19}$. Egzotyczny, w takim miejscu, element językowy, np.: Nomen omen, Ars moriendi, Finis terrae, Mea culpa, Homo sapiens, Camera obscura 'przen. świadectwa ciemnoty', Silva rerurm 'przen. rzeczy różne', Sancta simplicitas 'święta cierpliwość', zwraca na siebie uwagę, prowokuje i przyciaga czytelnika. Odchodzenie od informowania neutralnego przejawia się zwłaszcza w przywoływaniu latynizmów jako składników konstrukcji hybrydalnych, gdzie zderzone $\mathrm{z}$ wyrazami rodzimymi lub zapożyczeniami $\mathrm{z}$ innych języków dają efekt zaskoczenia i ekspresji, nie pozbawiony efektów komicznych: Watęsa recidividus (powracający), Victoria premiera, Memento dla ajatollahów, Exodus Hutu.

Jak $\mathrm{z}$ tego lapidarnego przedstawienia wynika, makaronizmy łacińskiego pochodzenia pełnią $w$ badanych tekstach prasowych różne funkcje, poza nazywaniem konkretnych pojęć i kondensowaniem treści, są ważnym elementem retorycznym $\mathrm{i}$ atrakcyjnym ozdobnikiem stylistycznym, który znacząco podnosi wartość estetyczną tekstu. W największym jednak stopniu o przywołaniu latynizmu decydują inne względy, nie potrzeby nazwania czy ekspresji, lecz snobistyczne upodobania autorów, którzy, jak w czasach sarmackich, widzą w makaronizmach dowód dobrego pochodzenia i starannego wykształcenia.

$\mathrm{Na}$ trzecim miejscu, pod względem ilości, w analizowanych tekstach prasowych znalazły się wtręty $\mathrm{z}$ języka francuskiego, który próbuje utrzymać dawną wysoką rangę języka elity intelektualnej, dialogu dyplomatycznego, bohemy artystycznej, ale chyba bez większego powodzenia. Przewagę mają tu pojedyncze przykłady zakorzenionych, zwłaszcza w języku inteligencji, utartych powiedzeń typu: par excellence, spécialité de la maison, à la carte, vis à vis, tete à tete, dossier, menu, à propos, à rebours, excusez le mot, faux pas, enfant terrible, carte blanche, savoir-vivre, resume, déjà vue 'złudzenie', entourage

19 G. Majkowska, H. Satkiewicz, op.cit., s. 185. 
'środowisko', coute que coute 'za wszelką cenę'. W materiale mamy też kilka terminów zaczerpniętych $\mathrm{z}$ języka dyplomatycznego: exposé, démarche 'protest', attaché, désintéreseement, dementi, chargé d'affaires, ancien régime, porte parole 'upełnomocniony mówca'. Leksykę świata mody reprezentuja wyrażenia: haute couture, pret-à-porter, bouclé, écru, dessous, frotté, słownictwo sportowe: coupé, grand prix, zaś historię, sferę sztuki i literatury: nouveau roman, femme fatale, fin de siècle, bon-mot 'zręczne wyrażenie', grand guignol 'postać $\mathrm{z}$ teatru marionetek; kpiarz', emploi, danse macabre, grand nation, empire, noblese oblige, le roi est mort, vive le roi 'umarł król, niech żyje król'. O niewielkiej sile oddziaływania francuskiego na współczesną polszczyznę pisaną świadczy fakt, że - $\mathrm{w}$ odróżnieniu od materiału $\mathrm{z}$ języka angielskiego - bardzo skromnie reprezentowane są tu makaronizmy okazjonalne, w całym analizowanym materiale pojawiło się tylko kilka wyrażeń tego typu, np.: femme de menage 'prywatna sprzątaczka', embawas de vischesse.

Nieco wbrew oczekiwaniom, okazuje się, że język współczesnej polskiej prasy czerpie makaronizmy także $\mathrm{z}$ jezzyka niemieckiego. Jest to o tyle niespodziewane, że język niemiecki nie cieszył się w Polsce nigdy ani wysokim prestiżem, ani sympatią a jego oddziaływanie na polszczyznę było najczęściej rezultatem źle kojarzących się w świadomości polskich użytkowników języka wydarzeń politycznych, militarnych, ekonomicznych itp. Dlatego też makaronizmy niemieckie, nawiązujące $w$ treści do tych nacechowanych emocjonalnie faktów $\mathrm{z}$ przeszłości mają na ogół wyraźne uczuciowe zabarwienie, najczęściej pejoratywne, jak ma to miejsce $w$ wypadku przykładów: Drang nach Osten, Arbeit macht frei, Blitzkrieg, Wunderwaffe, Kulturkampf, eine Mauer trent das deutsche Volk 'mur dzieli naród niemiecki', Deutschland erwache 'przebudzenie Niemiec', Ordnung muss sein. Inna sprawa, że te wyrażenia występują coraz częściej w zupełnie nowych kontekstach. W związku z tym nie tylko uzyskują nowe sensy, nierzadko metaforyczne, ale także neutralne, a nawet dodatnie konotacje. Dzieje się tak na przykład wtedy, kiedy Blitzkrieg nazywa zwycięstwo w szachach, Wunderwaffe dotyczy atrakcyjnej modelki lub gwiazdy muzyki rozrywkowej, zaś Drang nach Osten ilustruje fakt powrotu wielu polskich emigrantów z lat 80-tych do ojczyzny.

Przesunięcia semantyczne dokonujące się w przywołanych przykładach wskazują na zmiany zachodzące w obrębie funkcjonującego w Polsce stereotypu 
Niemiec i obywateli państwa niemieckiego ${ }^{20}$. Zjednoczonych Niemiec nie odbiera się dziś w kategoriach zagrożenia politycznego czy militarnego. Wręcz przeciwnie, państwo niemieckie będące przedstawicielem kultury zachodniej i znaczącym członkiem unii europejskiej, ze swoimi wpływami politycznymi, potęgą ekonomiczną i znanym $z$ wysokiej jakości produktem staje się przede wszystkim pożądanym partnerem politycznym i kulturalnym, choć najczęściej handlowym. Stąd powszechna wśród Polaków znajomość wyrażenia: herrgestellt in Deutschland, z którym korespondują inne, świadczące wprawdzie o bezpośrednich związkach gospodarczych polsko-niemieckich, ale nie zawsze najbardziej prestiżowych czy oficjalnie oczekiwanych, np. polnische Wirtschaft, polnische Markt, Polenmarkt, Fehler in alle Teile 'usterka w każdej części', gastarbeiter. Flohmarkt 'pchli targ', Kaufrausch 'szał zakupów', grosse Ausverkauft 'wielka wyprzedaż'.

Towarzyszą im makaronizmy obyczajowe, na ogół okazjonalne, nawiązujące zwłaszcza do miejsca kobiety w społeczeństwie niemieckim: Küche, Kirche, Kinder, Hausfrau, Frauenhaus 'dom dla kobiet potrzebujących pomocy', lub dotyczące sposobu bycia, jak: kindersztuba, szwarccharakter, schadenfreude 'radość z cudzego nieszczęścia', besserwisser 'ktoś wszystko i lepiej wiedzący', ale też wiążące się z turystyka, w tym sentymentalnymi podróżami obywateli Niemiec na polskie Pomorze, Warmię i Mazury: Heimat, Vaterland, reisefieber, zimmer frei.

Nieliczne makaronizmy włoskie, poza terminologią muzyczna, dotyczą w głównej mierze sfery bytowej, zwłaszcza kuchni: pizza, spaghetti, lasagna, capuccino, grappa, tortellini, ravioli, frutti di mare, tutti frutti, ale też zjawisk z zakresu szeroko pojmowanej kultury: commedia del 'larte, a capella, cicerone, $\mathrm{w}$ tym kultury popularnej i sportu: paparazzo, capo di tutti capi, dolce vita, suadra azzurra 'określenie sportowej reprezentacji Włoch', catenaccio, calcio (style gry w piłkę nożną), salto mortale.

Makaronizmy $\mathrm{z}$ innych języków niż wymienione mają $\mathrm{w}$ badanych tekstach znikomy udział. Za wyjątkowe lub sporadycznie notowane można uznać wtręty rosyjskie, zwłaszcza kluczowe słowa polityki Gorbaczowa

20 J. Bartmiński, Jak zmienia się stereotyp Niemca w Polsce, „Przegląd Humanistyczny” 5, 1994, s. 81-101. 
pierestrojka i głasnost'. Jedynym dostrzeżonym bohemizmem jest kuponowka 'forma uwłaszczenia zastosowana w Czechach'. Równie rzadko spotykamy elementy zaczerpnięte $\mathrm{z}$ języków orientalnych, są to głównie cytaty rzeczowe: dzihad 'święta wojna', intifada 'masowy protest przeciw izraelskiemu okupantowi', fatwa 'klątwa', czebol 'koreański koncern przemysłowy' itp.

Wydaje się, że przedstawione tu w skromnym wyborze różnojęzyczne makaronizmy, w większości oryginalne cytaty, ale też w nieznacznym stopniu przyswojone wyrazy i wyrażenia obcojęzyczne, zróżnicowane pod względem postaci i zakresu tematycznego, o rozmaitym nacechowaniu stylistycznym i emocjonalnym, dobrze ilustrują charakter współczesnego polskiego makaronizmu, języka polskich mediów (nie tylko) pisanych. Jednocześnie stopień „makaroniczności” analizowanych tekstów, wysoka frekwencja tekstowa sporej części cytatów i mało przyswojonych zapożyczeń, zróżnicowanie pełnionych przez nie funkcji są wymownym dowodem na to, że zastosowanie wobec tekstów nimi nasyconych terminu (neo)makaronizm nie jest nadużyciem. 